\title{
Exploring the Nature of Material Information: Disclosure and Its Implications
}

\author{
Ya-Fang Wang ${ }^{1} \&$ Hua-Wun Syu ${ }^{1}$ \\ ${ }^{1}$ Department of Accounting, Providence University, Taichung City, Taiwan \\ Correspondence: Ya-Fang Wang, Department of Accounting, Providence University, Taichung City, Taiwan. Tel: \\ 886-4-2632-8001 ext. 13216. E-mail: yfwang2@ @u.edu.tw
}

Received: July 14, 2015

Accepted: July 28, 2015

Online Published: September 25, 2015

doi:10.5539/ijef.v7n10p10

URL: http://dx.doi.org/10.5539/ijef.v7n10p10

\begin{abstract}
Understanding the nature of material information_is of crucial importance to regulators and the investment community, particularly with regard to the implications of disclosure. This study examined the disclosure of material information by companies listed in Taiwan in various stages of their life cycle to identify the nature of material information as well as related firm performance and provides insights into their causes and consequences. Evidence suggests that companies intent on fulfilling their corporate social responsibilities are more likely to disclose material information and when doing so, they are highly valued by market participants. Our empirical results provide strong evidence that the disclosure of material information by socially responsible companies is associated with higher earnings quality. Furthermore, mature companies are more likely than growing companies to receive favorable reactions from market participants when they disclose material information.
\end{abstract}

Keywords: material information, social responsibility, firm life cycle, firm value, earnings quality

\section{Introduction}

Taiwan's reputation as a gourmet destination has suffered through a series of food safety scandals (e.g., Chang Chi Foodstuff Factory Co., Flavor Full Food Inc. and Ting Hsin International Group). Many countries also substantially report the "adulterated oil" scandal and vigorously denounce dishonest food manufacturers. In this event, Taiwan learns a valuable lesson from these food safety scandals, and these scandals also give Taiwan's government a great challenge of how restore public confidence and rebuild Taiwan's reputation as a gourmet kingdom. After the "adulterated oil" scandal, the government of Taiwan proclaimed that it will impose harsher penalties on unscrupulous vendors; however, consumer confidence remains low. In flooding the market with adulterated cooking oil, Ting Hsin ignored safety issues and his social responsibility and the ethics of entrepreneurship issues in the pursuit of profit at the expense of health and life of people, and caused irreparable damage on the public. Suffering a series of food safety scandals, the public begin to pay attention to the importance of social responsibility and think how to promote the implementation of social responsibility. Corporate social responsibility (hereafter, CSR) is a people-oriented corporate culture in which product safety and consumer rights are paramount. Hence, encouraging companies to fulfill CSR is particularly important, because companies of the fulfillment of social responsibility (hereafter, CSR companies) are more likely to reject illegal act when they face the beneficial temptation.

One key to sustainable operations is to bear in mind CSR in the full weight of any corporate decision. CSR companies are more likely to disclose material information (hereafter, MI) when they think such information is important to corporate decisions and are therefore more likely to win trust and respect from customers and stockholders. This study examined the relationship between implementing CSR and the likelihood of the disclosure of MI as well as the economic consequences of these actions. We began by examining whether CSR companies are likely to disclose MI when they think the public has the right to know. We then examined how the valuation of external investors is affected when a company fulfills its CSR through the disclosure of MI. Third, We examined whether the disclosure of MI reflects the quality of financial reporting. We also examined the above-mentioned research questions from the perspective of the life cycle of CSR companies.

We began by determining the status of companies with regard to the implementation of their CSR by reading press releases on corporate websites. We then hand collected disclosures of MI, which was classified into six 
categories according to the rules of the Taiwan Stock Exchange. Our results indicate a significant, positive association between CSR companies and the likelihood of MI being disclosed. We also found that the disclosure of MI by CSR companies increases valuation by external investors and reflects the quality of financial reporting. We also found that the above-mentioned results are affected by the life cycle stage of the company.

This paper contributes to the literature as follows. Our results imply that CSR companies are more willing to fill transparency gaps by disclosing MI when faced with important decisions. Previous studies (Al-Akra \& Ali, 2012; Kohlbeck \& Mayhew, 2010; Brown \& Caylor, 2006) indicated only that disclosure has a positive association with firm value, while this study provides direct evidence that CSR companies are more likely to obtain favorable reactions from investors when they issue MI. These findings indicate that CSR is among the most important reputation assets of a company and that market participants perceive such disclosure as responsible behavior. Third, previous studies (Ertimur, Sletten, \& Sunder, 2011; Brown, Hillegeist, \& Lo, 2009; $\mathrm{Li}, 2006,2008$; Bloomfield, 2008) found that disclosures are often associated with uncertainty in a firm's operations. This study takes the examination further by demonstrating that the disclosure of MI by CSR companies may reflect in the quality of financial reporting. These findings provide a valuable reference for market participants and policy makers.

In the following section, we present a review of the literature and develop our hypotheses. Section 3 describes the sample selection procedure and research design. Section 4 presents the empirical results and additional analyses. Section 5 concludes the study.

\section{Literature Review}

Many studies have reported that corporate disclosure can reduce inefficiency in the market and identified the factors underlying the motives of mangers in the voluntarily disclosure of information (Core, 2001; Healy \& Palepu, 2001; Diamond \& Verrecchia, 1991). Some studies further reported that disclosure decisions are associated with management incentives (Merkley, 2014; Kravet \& Muslu, 2013; Davis, Piger, \& Sedor, 2012; Price, Doran, Peterson, \& Bliss, 2012; Loughran \& McDonald, 2011; Henry, 2008; Li, 2006). This study differs from above-mentioned studies in attempting to examine the relationship between the disclosure of MI and CSR companies by examining whether CSR companies are more likely to disclosure the MI, because CSR matters to the market, and assessments of CSR can potentially provide useful and timely information to investors. When a company fulfills its CSR through the disclosure of MI, market participants may interpret disclosure decisions as responsible behavior. In this study, we argue that CSR companies are more likely to disclose MI. The following hypothesis is developed:

$\mathrm{H}_{1}$ : The disclosure of material information is positively associated with corporate social responsibility.

Corporate disclosure is associated with information asymmetry and agency conflicts between managers and outside investors. Corporate disclosure can reduce the information gap and mitigate the problems associated with misevaluation (Healy \& Palepu, 2001; Leuz \& Verrecchia, 2000; Kim \& Verrecchia, 1994; Healy \& Palepu, 1993; Lundholm, 1991; Diamond \& Verrecchia, 1991; Amihud \& Mendelson, 1986; Glosten \& Milgrom, 1985; Diamond, 1985; Grossman, 1981; Milgrom, 1981). Previous studies have reported a link between corporate disclosure and economic consequences. For example, if a firm can reduce information asymmetry through disclosure prior to seasoned equity offerings, any negative reaction to the disclosure should be mediated (Lang \& Lundholm, 2000). Sengupta (1998) and Welker (1995) found that disclosures related to quality are associated with the costs of issuing debt. The degree of disclosure is associated with transaction costs and the cost of equity capital (Kristandl \& Bontis, 2007; Verrecchia, 2001; Piotroski, 1999; Botosan, 1997; Greenstein \& Sami, 1994; Barry \& Brown, 1986). Francis, Nanda, and Olsson (2008) found that firms engaging in more extensive disclosure face lower costs in debt and equity.

Previous studies have indicated that corporate disclosure can affect firm value via firm risk and expected future cash flow (Al-Akra \& Ali, 2012; Lang, Raedy, \& Yetman 2003). However, previous research on changes in firm value following corporate disclosure has had mixed results (Li, 2010; Nagar, Nanda, \& Wysocki, 2003; Bamber \& Cheon, 1998; Grossman, 1981; Milgrom, 1981), such that no consensus has been reached with regard to the relationship between corporate disclosure and the value of a firm. One reason for these mixed results may be a failure to consider the motivation behind and nature of disclosures. This study thus represents a good opportunity to re-examine and extend previous empirical findings by focusing solely on the disclosure of MI, which differs fundamentally from common disclosure and is of particular importance to regulators and the investing public. Generally speaking, the disclosure of MI is interpreted as a clarification of previous incorrect reporting or unfavorable news. This study thus argues that disclosures aimed at rectifying previous erroneous reports may be interpreted as an indication of CSR companies and therefore garner a positive reaction. It is also possible that 
market participants may consider such disclosures a sign of unfavorable news and react negatively. As a result, this study makes the following hypothesis:

$\mathrm{H}_{2}$ : Firm value is associated with the disclosure of material information.

The disclosure of MI may affect the valuation as determined by external investors. Therefore, we examined whether such disclosures reflect the quality of internal financial reporting. Researchers (Lobo \& Zhou, 2001) previously identified a negative correlation between earnings management and corporate disclosure. A number of studies also found that the disclosure of information can improve earnings quality (Bartholdson \& Goethe, 2011; Noravesh \& Hosseini, 2009; Francis et al., 2008). Iatridis and Alexakis (2012) found that corporate disclosure can reduce earnings manipulation, such that share prices are a more reliable reflection of a firm's financial health. As mentioned above, corporate disclosure appears to be related to earnings quality; however, the precise nature of this relationship remains unclear. This study argued that previous researchers disregarded the fact that corporate disclosures may differ considerably with regard to information content and may therefore vary in their effects on earnings quality. Specifically, MI included in the disclosure may provide a more accurate indication of the true nature of the earnings quality. This study presents the following hypothesis:

$\mathrm{H}_{3}$ : Earnings quality is associated with the disclosure of material information.

\section{Research Methodology}

\subsection{Sample Description}

Our sample comprised 6,839 firm-year observations associated with firms listed on the Taiwan Stock Exchange over the period from 2007 to 2012. Our sample period began in 2007 because it was at that time that information related to CSR became available. This sample was identified through two sources. We began by hand collecting data related to the nature of MI disclosures and CSR companies from the Market Observation Post System (hereafter, MOPS) and the Gre Tai Securities Market (hereafter GTSM). We then accessed company-level data related to accounting from the Taiwan Economic Journal (TEJ) database.

Panel A of Table 1 presents the yearly distribution of 6,839 firm-year observations, showing a slightly increasing trend in the disclosure of MI in the subsample during sample period. Panel B displays the distribution of MI classification and shows that most disclosures (88.45\%) were related to changes in business policy. As shown in Panel C, we collected 6,024 firm-year observations in the CSR subsample and 815 firm-year observations in the non-CSR subsample. Panel $\mathrm{C}$ also shows that mature companies account for most of the disclosures in the CSR subsample (51.24\%) as well as the non-CSR subsample (6.48\%).

Table 1. Sample distribution

\begin{tabular}{|c|c|c|c|c|c|c|c|c|c|}
\hline \multicolumn{10}{|c|}{ Panel A : Distributions of Material Information Disclosure } \\
\hline Disclosure ${ }^{\mathrm{a}}$ & 2007 & \multicolumn{2}{|c|}{2008} & 2009 & 2010 & \multicolumn{2}{|l|}{2011} & 2012 & Total \\
\hline MI & $\begin{array}{c}1,039 \\
(15.19 \%)\end{array}$ & \multicolumn{2}{|c|}{$\begin{array}{c}1,075 \\
(15.72 \%)\end{array}$} & $\begin{array}{c}1,124 \\
(16.44 \%)\end{array}$ & $\begin{array}{c}1,150 \\
(16.82 \%)\end{array}$ & $\begin{array}{c}1,183 \\
(17.30 \%)\end{array}$ & \multicolumn{2}{|c|}{$\begin{array}{c}1,199 \\
(17.52 \%)\end{array}$} & $\begin{array}{c}6,770 \\
(98.99 \%)\end{array}$ \\
\hline Non-MI & $\begin{array}{c}11 \\
(0.16 \%)\end{array}$ & \multicolumn{2}{|c|}{$\begin{array}{c}13 \\
(0.19 \%)\end{array}$} & $\begin{array}{c}11 \\
(0.16 \%) \\
\end{array}$ & $\begin{array}{c}11 \\
(0.16 \%)\end{array}$ & $\begin{array}{c}5 \\
(0.07 \%) \\
\end{array}$ & \multicolumn{2}{|c|}{$\begin{array}{c}18 \\
(0.27 \%)\end{array}$} & $\begin{array}{c}69 \\
(1.01 \%) \\
\end{array}$ \\
\hline Total & $\begin{array}{c}1,050 \\
(15.35 \%) \\
\end{array}$ & \multicolumn{2}{|c|}{$\begin{array}{c}1,088 \\
(15.91 \%) \\
\end{array}$} & $\begin{array}{c}1,135 \\
(16.60 \%) \\
\end{array}$ & $\begin{array}{c}1,161 \\
(16.98 \%) \\
\end{array}$ & $\begin{array}{c}1,188 \\
(17.37 \%) \\
\end{array}$ & \multicolumn{2}{|c|}{$\begin{array}{c}1,217 \\
(17.79 \%) \\
\end{array}$} & $\begin{array}{r}6,839 \\
(100 \%) \\
\end{array}$ \\
\hline \multicolumn{10}{|c|}{ Panel B : Distributions of Material Information Disclosure Classification } \\
\hline \multicolumn{4}{|c|}{ Disclosure $^{\text {Classification }^{\mathrm{b}}}$} & 3 & 4 & \multicolumn{2}{|c|}{5} & 6 & Total $^{\mathrm{c}}$ \\
\hline MI & \multicolumn{2}{|c|}{$\begin{array}{c}4,260 \\
(22.08 \%) \\
\end{array}$} & $\begin{array}{c}5,988 \\
(31.03 \%) \\
\end{array}$ & $\begin{array}{c}203 \\
(1.05 \%) \\
\end{array}$ & $\begin{array}{c}5,340 \\
(27.68 \%) \\
\end{array}$ & \multicolumn{2}{|c|}{$\begin{array}{c}3,363 \\
(17.43 \%) \\
\end{array}$} & $\begin{array}{c}140 \\
(0.73 \%) \\
\end{array}$ & 1,9294 \\
\hline \multicolumn{10}{|c|}{ Panel C : Distributions of Material Information Disclosure by CSR and Life Cycle } \\
\hline \multirow[t]{2}{*}{$\mathrm{Life} \mathrm{Cycle}^{\mathrm{CSR}^{\mathrm{e}}}$} & \multicolumn{4}{|c|}{ CSR } & \multicolumn{4}{|c|}{ Non-CSR } & \\
\hline & G & M & S & Subtotal & G & M & $S$ & Subtotal & Total \\
\hline MI & $\begin{array}{c}1,305 \\
(19.08 \%)\end{array}$ & $\begin{array}{c}3,504 \\
(51.24 \%)\end{array}$ & $\begin{array}{c}1,166 \\
(17.05 \%)\end{array}$ & $\begin{array}{c}5,975 \\
(87.37 \%)\end{array}$ & $\begin{array}{c}83 \\
(1.22 \%)\end{array}$ & $\begin{array}{c}443 \\
(6.48 \%)\end{array}$ & $\begin{array}{c}269 \\
(3.93 \%)\end{array}$ & $\begin{array}{c}795 \\
(11.62 \%)\end{array}$ & $\begin{array}{c}6,770 \\
(98.99 \\
\%) \\
\end{array}$ \\
\hline
\end{tabular}




\begin{tabular}{lccccccccc}
\hline \multirow{2}{*}{ Non-MI } & 7 & 35 & 7 & 49 & 1 & 13 & 6 & 20 & 69 \\
& $(0.10 \%)$ & $(0.51 \%)$ & $(0.10 \%)$ & $(0.71 \%)$ & $(0.01 \%)$ & $(0.19 \%)$ & $(0.09 \%)$ & $(0.30 \%)$ & $(1.01 \%)$ \\
\hline \multirow{2}{*}{ Total } & 1,312 & 3,539 & 1,173 & 6,024 & 84 & 456 & 275 & 815 & 6,839 \\
& $(19.18 \%)$ & $(51.75 \%)$ & $(17.15 \%)$ & $(88.08 \%)$ & $(1.23 \%)$ & $(6.67 \%)$ & $(4.02 \%)$ & $(11.92 \%)$ & $(100 \%)$ \\
\hline
\end{tabular}

${ }^{\mathrm{a}} \mathrm{MI}$ (Non-MI) denotes companies with (without) material information disclosures.

${ }^{\mathrm{b}}$ Material information can be divided into six categories: (1) material change in shareholder equity, (2) material change in business policy, (3) material disaster resulting in serious reduction or complete cessation of production, (4) material effect on shareholders' equity or company operations resulting from a change in laws, regulations, or rules of the home country, (5) mass media reportage about the parent company sufficient to affect securities prices of a listed subsidiary in the ROC, and (6) occurrence of any other material event that shall be immediately reported pursuant to law or regulation of the foreign company's home country.

${ }^{c}$ The numbers reported in Panel B is different because some companies announce material information more than one times in the same year.

${ }^{\mathrm{d}}$ CSR (Non-CSR) denotes companies of fulfilling corporate social responsibility with (without) material information disclosures.

${ }^{\mathrm{e}} \mathrm{G}$ denotes growth companies; M denotes maturity companies; S denotes decline companies.

\subsection{Research Design}

3.2.1 Disclosure of Material Information and Corporate Social Responsibility (H1)

We began by developing the following research model with which to examine the relationship between the disclosure of MI and CSR:

$$
\begin{aligned}
& M I_{i, t}=\alpha_{0}+\alpha_{1} \operatorname{CSR}_{i, t}+\alpha_{2} \text { ROA }_{i, t}+\alpha_{3} \operatorname{LOSS}_{i, t}+\alpha_{4} \operatorname{SIZE}_{i, t}+\alpha_{5} D E_{i, t}+\alpha_{6} \text { BDSIZE }_{i, t} \\
& +\alpha_{7} \text { INDBOD }_{i, t}+\alpha_{8} \text { CONTROL }_{i, t}+\alpha_{9} \text { DEVIATION }_{i, t}+\alpha_{10} \text { DUALITY }_{i, t} \\
& +\alpha_{11} Y E A R_{i, t}+\alpha_{12} I N D_{i, t}+\varepsilon_{i, t}
\end{aligned}
$$

In Eq. (1), dependent variable $M I$ is a dummy variable equal to 1 if the company disclosed $\mathrm{MI}$ in a given year; otherwise 0 . The test variable, CSR, is a dummy variable equal to 1 if the company fulfills its CSR in a given year; otherwise 0 . Our control variables include factors considered major determiners of whether a company is likely to disclose MI. In accordance with previous studies (Dhaliwal, Li, Tsang, \& Yang, 2011; Bamber, Jiang, Petroni, \& Wang, 2010), we considered three proxies for the financial condition of a company: ROA, LOSS, and $D E$. We predicted that the coefficient of $R O A$ was negative because profitable companies are less likely to disclose MI. We also predicted that the coefficient of $L O S S$ and $D E$ was positive because unprofitable companies are more likely to disclose MI. Corporate governance variables (BDSIZE, INDBOD, CONTROL, DEVIATION, and DUALITY) were included to control for the environment of corporate governance (Klein, 2002a, b; Dechow, Sloan, \& Sweeney, 1996; Beasley, 1996). We also included the companies' size effect (SIZE) as a control variable (Ettredge et al., 2011; Bens, Heltzer, \& Segal, 2011), because the size of a company could be used to capture firm-specific risk on earnings quality. We also included $Y E A R$ and IND as dummy variables in Eq. (1) to mitigate the problem of omitted variables in model estimation (Reynolds \& Francis, 2000). 
3.2.2 Firm Value and Disclosure of Material Information (H2)

Next, we examine the association between firm value and the disclosure of MI, using the following model:

$$
\begin{aligned}
\text { TOBINSQ }_{i, t}=\beta_{0} & +\beta_{1} M_{i, t}+\beta_{2} R O A_{i, t}+\beta_{3} \text { GROWTH }_{i, t}+\beta_{4} S I Z E_{i, t}+\beta_{5} D E_{i, t}+\beta_{6} R D_{i, t} \\
& +\beta_{7} S R D_{i, t}+\beta_{8} F C_{i, t}+\beta_{9} Y E A R_{i, t}+\beta_{10} I N D_{i, t}+\varepsilon_{i, t}
\end{aligned}
$$

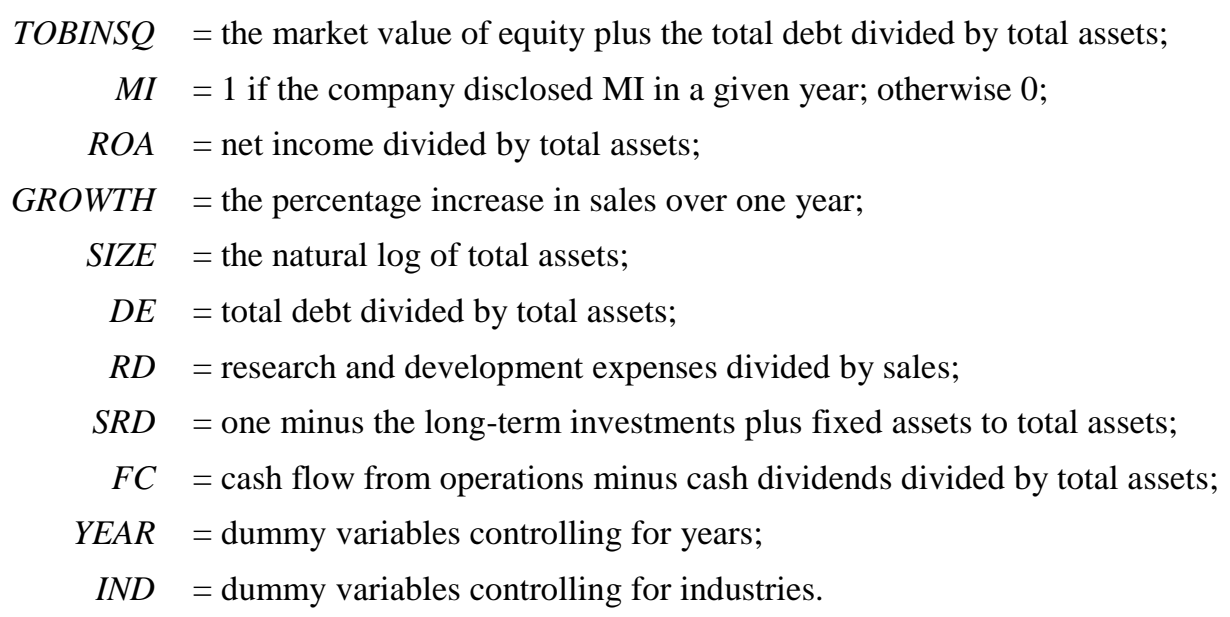

In Eq. (2), the dependent variable, TOBINSQ is equal to the market value of equity plus the total debt divided by total assets. In accordance with previous studies (Daske, Hail, Leuz, \& Verdi, 2008; Black, Jang, \& Kim, 2006; Lang \& Stulz, 1994; Morck, Shleifer, \& Vishny, 1988; Fisher \& McGowan, 1983), we employed TOBINSQ as a proxy for firm value in order to capture expected changes in future cash flow. From a review of the literature (Lang, Lins, \& Maffett, 2012; Abel \& Eberly, 2011; Eltayeb, 2011; Black et al., 2006; DeJong, Mertens, \& Wasley, 2005; Chung, Wright, \& Kedia, 2003; Allayannis \& Weston, 2001), this study includes four control variables from a review of the literature to control for the financial condition of a company: ROA, GROWTH, $\mathrm{DE}$, and FC. We expected a positive association between firm value and financial performance with the exception of leverage (DE). As in previous studies (Coles et al., 2008; Connolly \& Hirschey, 2005; Bosworth, 2002), we controlled for long-term R\&D activities (RD) and short-term R\&D activities (SRD) because both may give help to sustain the market value of the firm. Thus, we predicted a positive effect of R\&D activities on firm value. We also controlled for effects due to the company's size (SIZE).

\subsubsection{Earnings Quality and Disclosure of Material Information (H3)}

Finally, to test our hypothesis regarding whether the disclosure of MI is associated with earnings quality, we proposed the following research model:

$$
\begin{aligned}
\text { SMOOTH }_{i, t}= & \gamma_{0} \\
& +\gamma_{1} \text { MI }_{i, t}+\gamma_{2} \text { ROA }_{i, t}+\gamma_{3} \text { GROWTH }_{i, t}+\gamma_{4} \text { SIZE }_{i, t}+\gamma_{5} \text { LEV }_{i, t}+\gamma_{6} \text { BDSIZE }_{i, t} \\
& +\gamma_{7} \text { INDBOD }_{i, t}+\gamma_{8} \text { CONTROL }_{i, t}+\gamma_{9} \text { DEVIATION }_{i, t}+\gamma_{10} \text { DUALITY }_{i, t} \\
& +\gamma_{11} \text { YEAR }_{i, t}+\gamma_{12} I_{i, t}+\varepsilon_{i, t}
\end{aligned}
$$

\footnotetext{
SMOOTH = the standard deviation of net income before extraordinary items from $t-5$ to $t-1$, divided by the standard deviation of cash flow from operations from $t-5$ to $t-1$;

$M I \quad=1$ if the company disclosed $\mathrm{MI}$ in a given year; otherwise 0 ;

$R O A=$ net income divided by total assets;

GROWTH = the percentage increase in sales over one year;

SIZE = the natural log of total assets;

$L E V$ = long-term debt divided by total assets;

$B D S I Z E=$ number of directors on the board;

$I N D B O D=$ number of independent directors on the board divided by the total board size;

CONTROL = number of seat-control directors divided by the total board size;
} 


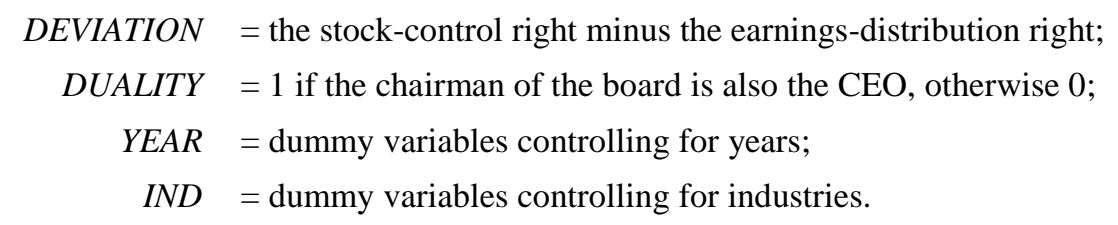

In accordance with previous studies (Martinez \& Castro, 2010; Myers, Myers, \& Skinner, 2007; Gassen, Flbier, \& Sellhorn, 2006; Burgstahler, Hail, \& Leuz, 2006; Francis, LaFond, Olsso, \& Schipper, 2004; Bhattacharya \& Sen, 2004; Leuz, Nanda, \& Wysock, 2003), we used the SMOOTH variable as a proxy for earnings quality, which is equal to the standard deviation of net income before extraordinary items from $\mathrm{t}-5$ to $\mathrm{t}-1$, divided by the standard deviation of cash flow from operations from t-5 to t-1. Regarding the control variables in Eq. (3), we followed the example in previous studies (Joseph, 2012; Tucker \& Zarowin, 2006; Brav \& Gompers, 2003; Frankel, Johnson, \& Nelson, 2002; Jelic, Saadouni, \& Briston, 1998; Mandelker \& Rhee, 1984; Hamada, 1972) with the inclusion of three control variables to control for the financial condition of a company: ROA, GROWTH, and LEV. We also included corporate governance variables (BDSIZE, INDBOD, CONTROL, DEVIATION, and DUALITY) to control for the governance environment of a company (Klein, 2002a, b; Dechow et al., 1996; Beasley, 1996). Finally, we included the company's size effect (SIZE) as a control variable, due to the fact that it may capture firm-specific risk associated with earnings quality (Mohammadi, Maharlouie, \& Maharlouie, 2012; Logue, 1973).

\section{Empirical Results}

\subsection{Descriptive Statistics and Univariate Tests}

Table 2 presents the descriptive statistics for all of the variables used in our analysis. Panel A was partitioned into two subsamples: companies that fulfill their CSR $(n=6,024)$, and company that do not fulfill their CSR $(n=$ 815). Panel A of univariate test results reveals that the disclosure of MI $(M I)$ is significantly higher in CSR firms $($ mean $=0.9919)$ than in non-CSR firms $($ mean $=0.9755 ; \mathrm{p}<0.01)$. The mean values of several variables related to corporate governance (BDSIZE, INDBOD, CONTROL, and DEVIATION) are significantly different between CSR and non-CSR firms (all p-values $<0.01$ ). Generally speaking, CSR firms have better corporate governance than do non-CSR firms. Panel B was partitioned into two subsamples: companies that disclosed material information $(\mathrm{n}=5,975)$, and companies that did not disclose material information $(\mathrm{n}=49)$. Panel $\mathrm{B}$, showing univariate comparisons, indicates that earnings quality $($ SMOOTH) is significantly higher in MI firms (mean = 0.8011 ) than in non-MI firms (mean $=1.1915 ; \mathrm{p}<0.01$ ). The mean value of SMOOTH in MI firms was nearly $50 \%$ higher than that of non-MI firms, indicating that the disclosure of MI tends to be associated with higher quality financial reporting.

This study adopted the methods outlined in previous studies (Black, 1998; Anthony \& Ramesh, 1992) by classifying firms according to the various stages in their life cycle: growing companies $(n=1,396)$, mature companies $(\mathrm{n}=3,995)$, and companies in decline $(\mathrm{n}=1,448)$. Growing companies were more likely than mature companies to disclose MI $(M I)$. They are also more likely to fulfill their CSR (CSR), and have significantly higher firm value (TOBINSQ). Growing companies were more likely than companies in decline to perform CSR $(C S R)$ and tended to have a significantly higher firm value (TOBINSQ). Mature companies were more likely than companies in decline to perform CSR (CSR) and tended to have significantly higher firm value (TOBINSQ). These results indicate that growing companies are the most likely to perform CSR and tend to have higher firm value. Finally, growing companies tended to have higher R\&D activities $(R D)$ and leverage $(L E V)$ than were mature and companies in decline. Growing companies also have audit committees that are more independent (INDBOD) and tend to have stronger control rights (CONTROL).

Table 3 lists the Pearson correlation coefficients for the test and control variables used in the proposed research models. The correlation between the disclosure of MI $(M I)$ and earnings quality $(S M O O T H)$ was in the predicted direction (statistically significant at the 0.01 level), except for TOBINSQ, which was insignificantly positive. These results imply that companies disclosing MI are more commonly associated with high quality financial reporting. MI was also shown to be correlated with LOSS (-0.046), SIZE (0.051), and BDSIZE (0.034) (statistically significant at the 0.01 level), suggesting that larger companies, and those with less pronounced losses and stronger corporate governance were more strongly associated with the disclosure of MI. We further computed variance inflation factors (VIF's) to test for the possibility of multicollinearity among all variables. None of the VIFs exceeded 10, indicating that our empirical results were not affected by multicollinearity (Kennedy, 1998). 
Table 2. Descriptive statistics

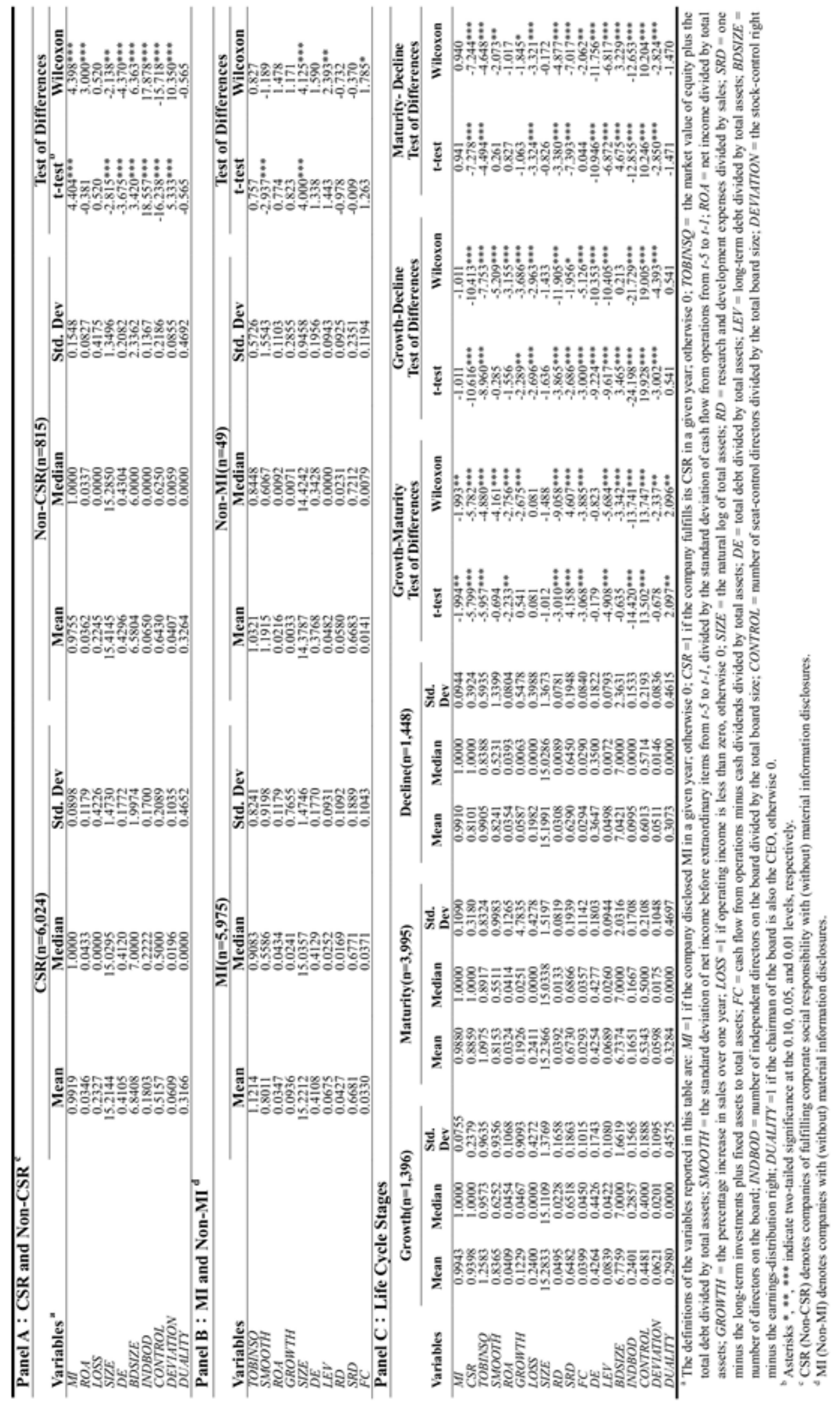




\subsection{Multivariate Analysis}

\subsubsection{Disclosure of Material Information and Corporate Social Responsibility (H1)}

Our first hypothesis deals with the relationship between the disclosure of MI and CSR. Table 4 presents estimates from a probit regression of Eq. (1). In column (1), the coefficient of CSR is 0.399 (significant at p < 0.01 ), suggesting that CSR companies are more likely to disclose MI. We further explored the relationship between the disclosure of MI and CSR in various stages of a company's life cycle by partitioning the sample into three groups: growing companies, mature companies, and companies in decline. In columns (2) and (4), the coefficient of CSR is positive but not significant, whereas the coefficient of CSR in column (3) is significant and positive ( $\mathrm{p}<0.01$ ). These findings suggest that mature companies fulfilling CSR are more likely to disclose MI than growing companies and those in decline. In protecting rights and interests, mature companies that fulfill CSR are more likely to risk disclosing information to market participants. For control variables, the coefficients related to a company's financial condition (ROA and LOSS) were significantly negative, while the coefficients of company size (SIZE) and corporate governance (DEVIATION and DUALITY) were significantly positive. The coefficients for control variables are generally significant and have the expected signs.

\subsubsection{Firm Value and Disclosure of Material Information (H2)}

As discussed previously, CSR companies are more likely to disclose MI. Our second hypothesis deals with whether the disclosure of MI by CSR companies affects the perceptions of market participants and thereby affects firm value. Table 5 presents the results of regression analysis, which indicate that $M I$ is positively associated with firm value $(\mathrm{p}<0.05)$ in the total sample. This indicates that CSR companies that disclose MI increase beneficial effects on firm value. Next, we partitioned the sample into different life cycle stages to explore whether different life cycle stages may affect the association between MI disclosed and firm value. In column (2), the coefficient of $M I$ is insignificantly positive whereas the coefficient on $M I$ in column (4) is significantly positive (at least at the $1 \%$ significance level), suggesting that mature and decline CSR companies are more likely to receive favorable reactions of market participants than growing companies of fulfilling CSR. A possible reason underlying this finding is that market participants react favorably to mature and declining CSR companies because such MI at different life cycle stages is interpreted as a signal of protecting the companies' rights and interests, and information disclosed at different life cycle stages affects market participants' valuation of firm value.

According to the laws stated in the Taiwan Stock Exchange Corporation Procedures for Verification and Disclosure of Material Information of Companies with Listed Securities, this study further classifies MI into six categories to capture the nature of MI from different perspectives. Table 6 reports results for the nature of MI regressions in different life cycle stages. Panel A shows that, after considering the nature of MI, coefficients of $M I$ are insignificant in columns (1), (2), (4), and (6). Importantly, the coefficient of $M I$ is significant and negative in column (3) whereas the coefficient of $M I$ is significant and positive in column (5). Panel B shows that coefficients of $M I$ are significant and positive in columns (1), (5), and (6). Panel C shows that coefficients of $M I$ are significant and positive in columns (1) and (5). These findings suggest that MI disclosed at different life cycle stages will affect firm value differently by focusing on the nature of MI. Notably, coefficients of the fifth MI disclosure are significant and positive, regardless of whether the fifth MI is disclosed in growth, mature or declining companies. This result indicates that market participants view the fifth MI disclosure as a signal that clarifies incorrect media reportage and that they react positively. Overall, the empirical results support our conjecture that market participants react differently to MI disclosed at different life cycle stages. 
Table 3. Pearson correlation coefficients for the CSR sample

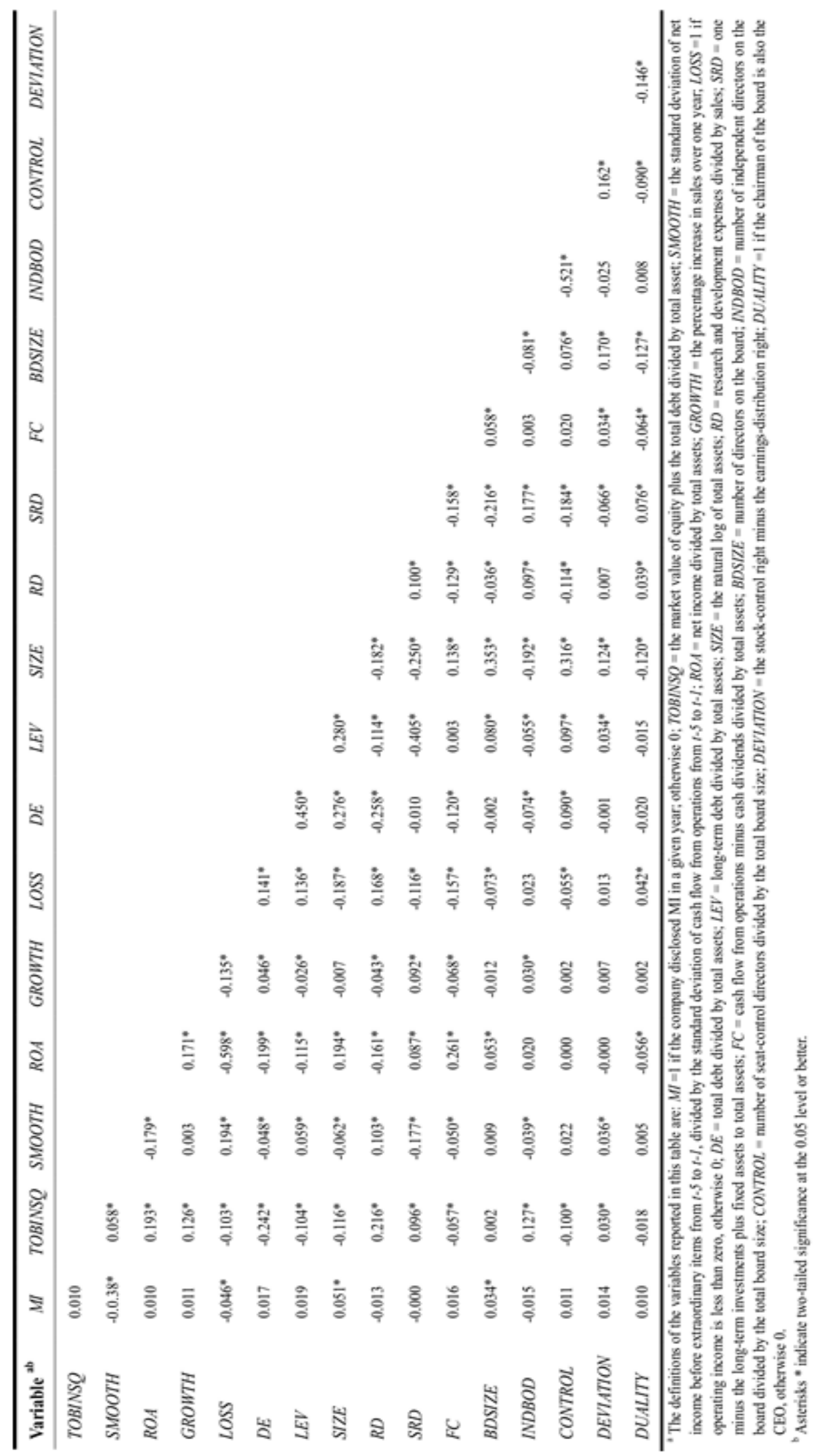


Table 4. Material information disclosure and corporate social responsibility

\begin{tabular}{|c|c|c|c|c|c|c|c|c|c|}
\hline \multirow[b]{2}{*}{ Variables $^{\mathrm{a}}$} & \multirow[b]{2}{*}{ Pred. Sign } & \multicolumn{2}{|c|}{$\begin{array}{c}\text { (1) } \\
\text { Total sample }\end{array}$} & \multicolumn{2}{|c|}{$\begin{array}{c}\text { (2) } \\
\text { Growth }\end{array}$} & \multicolumn{2}{|c|}{$\begin{array}{c}\text { (3) } \\
\text { Maturity }\end{array}$} & \multicolumn{2}{|c|}{$\begin{array}{c}(4) \\
\text { Decline }\end{array}$} \\
\hline & & Coef. & $z$-value ${ }^{\mathrm{b}}$ & Coef. & $z$-value & Coef. & $z$-value & Coef. & $z$-value \\
\hline CONSTANT & & -1.3240 & $-2.27 * *$ & -3.6750 & $-2.29 * *$ & -1.6341 & $-2.41^{* *}$ & 0.9971 & 0.77 \\
\hline CSR & + & 0.3990 & $3.20^{* * * *}$ & 0.4269 & 1.14 & 0.4968 & $3.12 * * *$ & 0.0723 & 0.33 \\
\hline$R O A$ & - & -0.8533 & $-2.05^{* *}$ & -3.2908 & $-2.67 * * *$ & -0.9705 & $-1.99 * *$ & 1.2503 & $1.34 *$ \\
\hline LOSS & - & -0.4311 & $-3.30 * * *$ & -1.0827 & $-2.43 * * *$ & -0.4074 & $-2.71 * * *$ & -0.2308 & -0.63 \\
\hline SIZE & $+1-$ & 0.1863 & $4.95 * * *$ & 0.3356 & $2.15 * *$ & 0.2208 & $5.06 * * *$ & 0.0095 & 0.13 \\
\hline$D E$ & + & 0.3905 & 1.32 & -0.0124 & -0.02 & 0.2811 & 0.75 & 1.0489 & $1.31 *$ \\
\hline$B D S I Z E$ & $+/-$ & 0.0288 & 0.87 & -0.0901 & -0.54 & -0.0000 & -0.00 & 0.1567 & $2.08 * *$ \\
\hline$I N D B O D$ & - & -0.1792 & -0.47 & 1.0532 & 0.96 & -0.4654 & -0.96 & 1.2904 & $1.29 *$ \\
\hline CONTROL & + & -0.2766 & -1.04 & -0.3198 & -0.29 & -0.0310 & -0.10 & -0.8567 & $-1.87 * *$ \\
\hline DEVIATION & + & 1.2754 & $1.99 * *$ & 4.2530 & $2.31 * *$ & 1.4755 & $1.71 * *$ & 2.4698 & $1.78^{* * *}$ \\
\hline DUALITY & + & 0.1943 & $1.79 * *$ & 1.1348 & $2.95 * * *$ & 0.2281 & $1.72 * *$ & 0.1227 & 0.57 \\
\hline$Y E A R$ & & Included & & Included & & Included & & Included & \\
\hline IND & & Included & & Included & & Included & & Included & \\
\hline Pseudo $\mathrm{R}^{2}$ & & $12.20 \%$ & & $35.11 \%$ & & $13.82 \%$ & & $17.97 \%$ & \\
\hline $\mathrm{n}$ & & 6,388 & & 575 & & 3,712 & & 1,012 & \\
\hline
\end{tabular}

${ }^{a}$ The definitions of the variables reported in this table are: $M I=1$ if the company disclosed $\mathrm{MI}$ in a given year, otherwise $0 ; C S R=1$ if the company fulfills its CSR in a given year; otherwise $0 ; R O A=$ net income divided by total assets; $L O S S=1$ if operating income is less than zero, otherwise $0 ; S I Z E=$ the natural $\log$ of total assets; $D E=$ total debt divided by total assets; $B D S I Z E=$ number of directors on the board; $I N D B O D=$ number of independent directors on the board divided by the total board size; $C O N T R O L=$ number of seat-control directors divided by the total board size; DEVIATION = the stock-control right minus the earnings-distribution right; DUALITY=1 if the chairman of the board is also the CEO, otherwise $0 ; Y E A R=$ fiscal year dummies; IND = dummy variables controlling for industries.

${ }^{\mathrm{b}}$ Asterisks *, **, *** indicate significance at the $0.10,0.05$, and 0.01 levels, respectively. One-tailed for directional expectations, two-tailed for others.

Table 5. Firm value and material information disclosure

\begin{tabular}{|c|c|c|c|c|c|c|c|c|c|}
\hline \multirow[b]{2}{*}{ Variables $^{\mathrm{a}}$} & \multirow[b]{2}{*}{ Pred. Sign } & \multicolumn{2}{|c|}{$\begin{array}{c}\text { (1) } \\
\text { Total sample }\end{array}$} & \multicolumn{2}{|c|}{$\begin{array}{c}(2) \\
\text { Growth }\end{array}$} & \multicolumn{2}{|c|}{$\begin{array}{c}\text { (3) } \\
\text { Maturity }\end{array}$} & \multicolumn{2}{|c|}{$\begin{array}{c}(4) \\
\text { Decline }\end{array}$} \\
\hline & & Coef. & $t$-value ${ }^{\mathrm{b}}$ & Coef. & $t$-value & Coef. & $t$-value & Coef. & $t$-value \\
\hline CONSTANT & & 1.1894 & $4.27 * * *$ & 1.2842 & $3.83^{* * *}$ & 1.9768 & $6.43^{* * *}$ & 1.5010 & $7.19^{* * *}$ \\
\hline$M I$ & $+1-$ & 0.1464 & $2.23 * *$ & 0.2148 & 1.20 & 0.1291 & 1.44 & 0.2503 & $5.90^{* * * *}$ \\
\hline$R O A$ & + & 1.3279 & $1.57 *$ & 2.6383 & $4.88^{* * *}$ & 0.7949 & 0.83 & 2.1289 & $6.67 * * *$ \\
\hline GROWTH & + & 0.0949 & $3.13^{* * *}$ & 0.0239 & 0.69 & 0.1309 & $4.03^{* * *}$ & 0.0230 & 0.48 \\
\hline SIZE & $+1-$ & -0.0284 & -1.64 & 0.0035 & 0.21 & -0.0368 & -1.58 & -0.0339 & $-2.27 * *$ \\
\hline$D E$ & - & -0.7036 & $-4.08^{* * *}$ & -1.4127 & $-7.18 * * *$ & -0.7114 & $-3.42 * * *$ & -0.1324 & -1.14 \\
\hline$R D$ & + & 1.4348 & $3.52^{* * *}$ & 1.4643 & $2.26^{* *}$ & 1.3080 & $3.47 * * *$ & 1.2048 & $2.41 * *$ \\
\hline$S R D$ & + & 0.1005 & 0.82 & 0.1504 & 1.11 & 0.1355 & 0.92 & -0.1651 & $-1.87 * *$ \\
\hline$F C$ & - & -0.6467 & $-1.48^{*}$ & -0.5593 & $-1.97 * *$ & -0.6907 & -1.11 & -0.2111 & -0.76 \\
\hline$Y E A R$ & & Included & & Included & & Included & & Included & \\
\hline$I N D$ & & Included & & Included & & Included & & Included & \\
\hline$R^{2}$ & & $21.55 \%$ & & $1.11 \%$ & & $7.31 \%$ & & $25.81 \%$ & \\
\hline $\mathrm{n}$ & & 6,024 & & 1,312 & & 3,539 & & 1,173 & \\
\hline
\end{tabular}

${ }^{a}$ The definitions of the variables reported in this table are: $T O B I N S Q=$ the market value of equity plus the total debt divided by total assets; $M I=1$ if the company disclosed $\mathrm{MI}$ in a given year, otherwise $0 ; R O A=$ net income divided by total assets; GROWTH = the percentage increase in sales over one year; $S I Z E=$ the natural $\log$ of total assets; $D E=$ total debt divided by total assets; $R D=$ research and development expenses divided by sales; $S R D=$ one minus the long-term investments plus fixed assets to total assets; $F C=$ cash flow from operations minus cash dividends divided by total assets; YEAR $=$ fiscal year dummies; $I N D=$ dummy variables controlling for industries.

${ }^{\mathrm{b}}$ Asterisks $* * *, * * *$ indicate significance at the $0.10,0.05$, and 0.01 levels, respectively. One-tailed for directional expectations, two-tailed for others.

\subsubsection{Earnings Quality and Disclosure of Material Information (H3)}

As mentioned above, MI disclosures affect external investors' valuation and, therefore, are associated with firm 
value. Next, our third hypothesis further examines whether these MI disclosures reflect internal financial reporting quality. Table 7 reports results of regression analysis and indicates that $M I$ is negatively associated with earnings quality $(\mathrm{p}<0.10)$ for the total sample, indicating that the disclosure of MI by CSR companies may be a reflection of the quality of financial reporting. We also partitioned the sample into the various stages of company life cycle in order to determine whether life cycle stage affects the relationship between the disclosure of MI and earnings quality. Surprisingly, the coefficient of $M I$ was significant $(\mathrm{p}<0.05)$ only in companies in decline, which implies that the disclosure of MI by companies in decline is associated with high quality financial reporting.

Table 8 presents the results related to the association between the nature of MI and earnings quality in different stages of a company's life cycle. Panel A shows that the coefficient of $M I$ in column (5) is significant and positive, indicating that the disclosure of MI by growing companies in response to media coverage is associated with poor earnings quality. Panel B show that only the coefficient of $M I$ in column (2) is significant and negative, whereas the coefficients of $M I$ in column (1) and (6) are significant and positive. This suggests that the disclosure by mature companies of MI based on company operations is associated with better earnings quality. Panel $\mathrm{C}$ shows that in companies in decline, only the coefficient of $M I$ in column (6) is significant and positive, indicating that the disclosure of MI related to foreign law or regulation is associated with better earnings quality. Overall, our empirical results support our conjecture that the life cycle stage in which the disclosure of MI occurs is an indication of differences in internal earnings quality. 
Table 6. Firm value and material information disclosure: the nature of material information

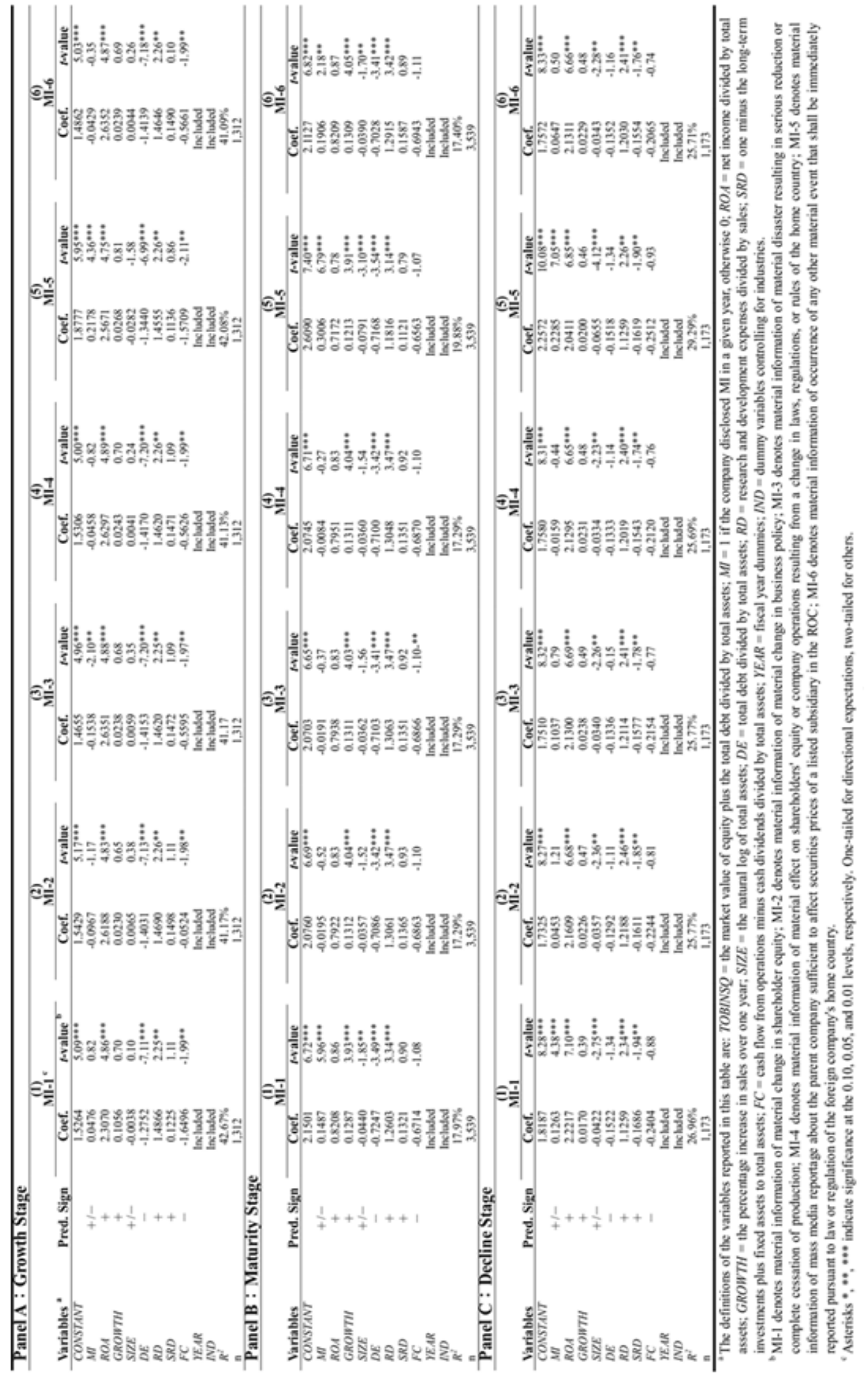


Table 7. Earnings quality and material information disclosure

\begin{tabular}{|c|c|c|c|c|c|c|c|c|c|}
\hline \multirow[b]{2}{*}{ Variables $^{\mathrm{a}}$} & \multirow[b]{2}{*}{ Pred. Sign } & \multicolumn{2}{|c|}{$\begin{array}{c}(1) \\
\text { Total sample } \\
\end{array}$} & \multicolumn{2}{|c|}{$\begin{array}{c}(2) \\
\text { Growth }\end{array}$} & \multicolumn{2}{|c|}{$\begin{array}{c}\text { (3) } \\
\text { Maturity }\end{array}$} & \multicolumn{2}{|c|}{$\begin{array}{c}(4) \\
\text { Decline }\end{array}$} \\
\hline & & Coef. & $t$-value ${ }^{\mathrm{b}}$ & Coef. & $t$-value & Coef. & $t$-value & Coef. & $t$-value \\
\hline CONSTANT & & 2.1164 & $5.86^{* * *}$ & 1.4184 & $4.14 * * *$ & 2.0865 & $5.87 * * *$ & 2.0621 & $1.91 * *$ \\
\hline MI & $+1-$ & -0.3716 & $-1.67 *$ & 0.0416 & 0.34 & -0.1292 & -0.70 & -2.0334 & $-1.99 * *$ \\
\hline$R O A$ & $+1-$ & -1.2750 & $-5.53 * * *$ & -1.0427 & $-3.46^{* * *}$ & -1.2605 & $-4.18 * * *$ & -1.7416 & $-4.15 * * *$ \\
\hline GROWTH & + & 0.0406 & $1.89 * *$ & 0.0061 & 0.37 & 0.0667 & $2.08 * *$ & 0.0259 & 0.73 \\
\hline SIZE & $+1-$ & -0.0420 & $-3.92 * * *$ & -0.0606 & $-2.87 * * *$ & -0.0746 & $-4.80 * * *$ & 0.0467 & $2.14 * *$ \\
\hline$L E V$ & + & 0.5746 & $3.77 * * *$ & 0.9608 & $2.36^{* * *}$ & 0.5458 & $3.17 * * *$ & 0.4318 & $1.34 *$ \\
\hline BDSIZE & $+1-$ & 0.0131 & $2.11 * *$ & 0.0143 & 0.68 & 0.0273 & $3.26^{* * *}$ & -0.0203 & $-1.74 *$ \\
\hline$I N D B O D$ & - & -0.2295 & $-2.71 * * *$ & -0.6864 & $-3.05 * * *$ & -0.2069 & $-1.93^{*}$ & 0.1485 & 0.79 \\
\hline CONTROL & + & 0.0238 & 0.31 & -0.1632 & -0.59 & 0.0911 & 1.13 & 0.0907 & 0.55 \\
\hline DEVIATION & + & 0.2834 & $1.62 *$ & 0.2249 & 0.61 & 0.4373 & $1.82 * *$ & -0.2290 & -0.95 \\
\hline DUALITY & + & -0.0152 & -0.58 & 0.0294 & 0.45 & -0.0581 & $-1.82 * *$ & 0.0792 & 1.33 \\
\hline YEAR & & Included & & Included & & Included & & Included & \\
\hline$I N D$ & & Included & & Included & & Included & & Included & \\
\hline$R^{2}$ & & $5.52 \%$ & & $6.90 \%$ & & $7.74 \%$ & & $12.89 \%$ & \\
\hline $\mathrm{n}$ & & 6,024 & & 1,312 & & 3,539 & & 1,173 & \\
\hline
\end{tabular}

${ }^{a}$ The definitions of the variables reported in this table are: $S M O O T H=$ the standard deviation of net income before extraordinary items from $t-5$ to $t-1$, divided by the standard deviation of cash flow from operations from $t-5$ to $t-1 ; M I=1$ if the company disclosed MI in a given year, otherwise 0; ROA = net income divided by total assets; GROWTH = the percentage increase in sales over one year; SIZE = the natural log of total assets; $L E V=$ long-term debt divided by total assets; $B D S I Z E=$ number of directors on the board; $I N D B O D=$ number of independent directors on the board divided by the total board size; CONTROL = number of seat-control directors divided by the total board size; DEVIATION = the stock-control right minus the earnings-distribution right; DUALITY $=1$ if the chairman of the board is also the CEO, otherwise $0 ; Y E A R=$ fiscal year dummies; $I N D=$ dummy variables controlling for industries.

${ }^{\mathrm{b}}$ Asterisks *, $* *, * * *$ indicate significance at the $0.10,0.05$, and 0.01 levels, respectively. One-tailed for directional expectations, two-tailed for others.

\subsection{Additional Tests}

\subsubsection{Consider the CEO Turnover}

Previous studies (Wilson \& Wang, 2010; Conyon \& Florou, 2004; Reitenga \& Tearney, 2003; Godfrey, Mather, \& Ramsay 2003; Wells, 2002; Brickley, Linck, \& Coles, 1999; Pourciau, 1993; Dechow \& Sloan, 1991) have indicated that CEO turnover is commonly related to earnings quality. Thus, we included a factor for CEO turnover in a reexamination of our third hypothesis, the results of which are listed in Table 9. Panel A shows that the CEO turnover rate was $14.03 \%$ in the subsample of companies the disclosed MI. Panel B lists the distribution by frequency of CEO turnover, indicating that first time CEO turnover was $89.23 \%$ in the subsample of companies the disclosed MI. Panel $\mathrm{C}$ lists the results of regression analysis, which indicate that the coefficient of $M I$ in the subsample of CEO turnover is significant and positive $(\mathrm{p}<0.10)$, whereas the coefficient of $M I$ in the subsample of non-CEO turnover is significant and negative $(\mathrm{p}<0.10)$. These results imply that companies experiencing CEO turnover are more likely to engage in earnings management by manipulating the disclosure of MI. As such, these firms tend to be associated with poor earnings quality.

\subsubsection{Consider the Probability of Restatement}

Previous studies (Ecker, Francis, Olsson, \& Schipper 2011; Plumlee \& Yohn, 2010) have suggested that restatements are the most visible indicator of poor earnings quality. Thus, we extended our third hypothesis using the probability of restatement as an alternative proxy for earnings quality. Table 10 shows that in the overall sample, $M I$ was insignificantly associated with restatements. We further partitioned the sample into Big 4 and non-Big 4 groups for further analysis. Empirical results indicate that the coefficient of $M I$ in the Big 4 group is negative but insignificant, whereas the coefficient of $M I$ in the non-Big 4 group is significant and positive ( $\mathrm{p}<$ 0.01). This implies that non-Big 4 clients are more likely to restate their financial reporting figures. We further partitioned the non-Big 4 sample according to their life cycle stage and found that only the coefficients of $M I$ for mature and companies in decline are significant and positive (not listed in the tables). 
Table 8. Earnings quality and material information disclosure: the nature of material information

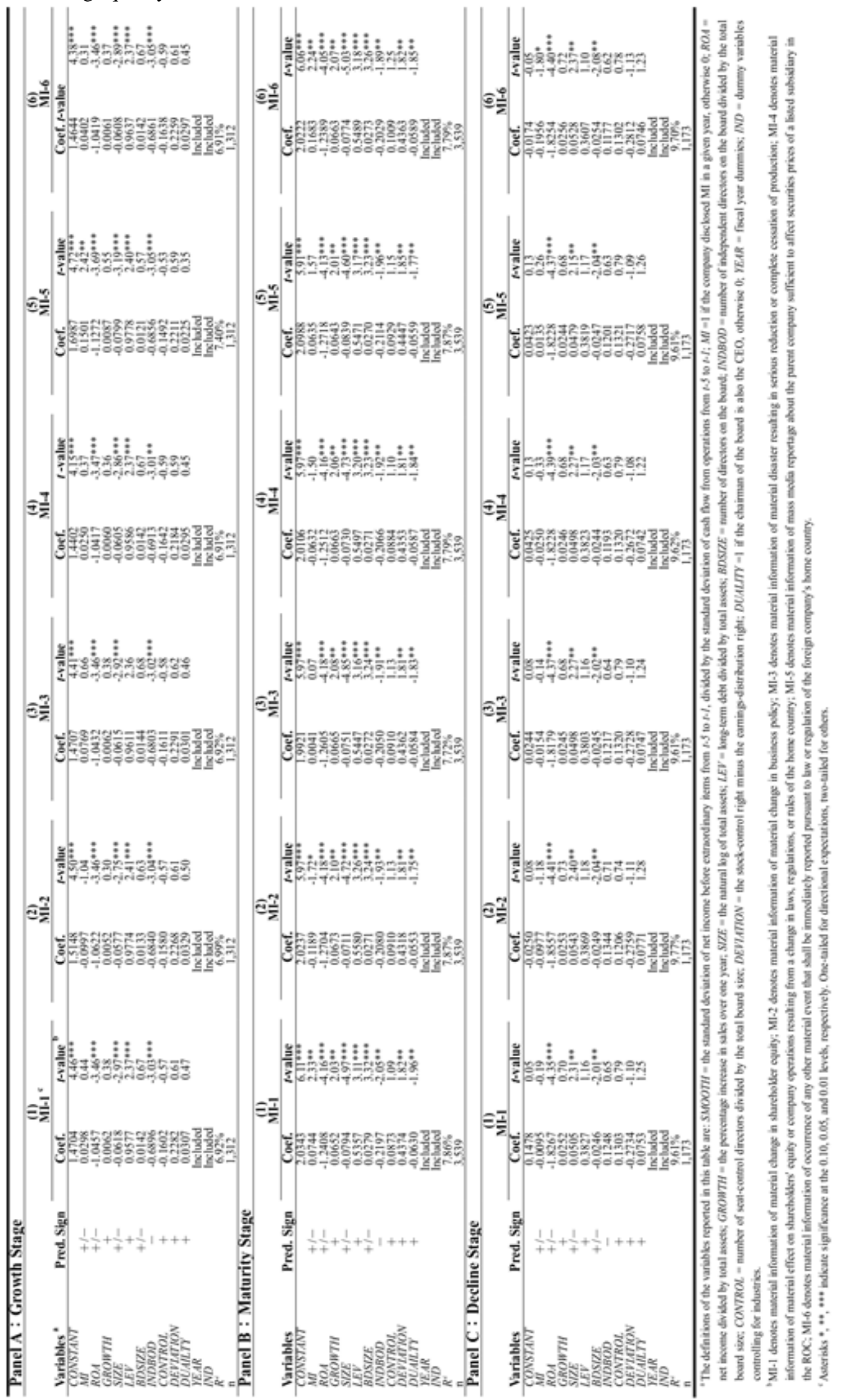




\subsection{Sensitivity Analyses (Not Tabulated)}

To ensure robustness in our results, we also used an alternative measure for the calculation of firm value based on the market value of equity plus the liquidating value of preferred stock and total debt divided by total assets (Chung \& Pruitt, 1994). After rerunning Eq. (2), we obtained results similar to those reported in the tables. In accordance with the methods outlined by Nissim (2002) and Michelson, Jordan-Wagner, and Wootton (1995), we also considered an alternative measure for calculating earnings quality based on the coefficient of variations in net income before extraordinary items over the first four years in a five-year period. Rerunning Eq. (3), the empirical results were similar to those reported in previous sections. Changes in auditor may also affect earnings quality and bias empirical analysis (DeFond \& Subramanyam, 1998); therefore, we excluded observations related to auditor change and reran the research models. The results and conclusions remained unchanged.

Table 9. Earnings quality and material information disclosure: consider CEO turnover

\begin{tabular}{|c|c|c|c|c|c|c|}
\hline \multicolumn{7}{|c|}{ Panel A : Distribution by Disclosure and CEO Turnover } \\
\hline $\begin{array}{l}\text { Turnover } \\
\text { Disclosure }\end{array}$ & & CEO Turnover & \multicolumn{3}{|c|}{ Non-CEO Turnover } & Total \\
\hline MI & & $845(14.03 \%)$ & & $5,130(85.16 \%)$ & & $5,975(99.19 \%)$ \\
\hline Non-MI & & $5(0.08 \%)$ & & $44(0.73 \%)$ & & $49(0.81 \%)$ \\
\hline Total & & $850(14.11 \%)$ & & $5,174(85.89 \%)$ & & $6,024(100 \%)$ \\
\hline \multicolumn{7}{|c|}{ Panel B : Distribution by Frequency of CEO Turnover } \\
\hline \multirow{2}{*}{ No. of CEO Turnover } & & 1 & 2 & 3 & 4 & Total \\
\hline & & $754(89.23 \%)$ & $81(9.59 \%)$ & $6(0.71 \%)$ & $4(0.47 \%)$ & $845(100 \%)$ \\
\hline \multicolumn{7}{|c|}{ Panel C : Regression Results } \\
\hline & & \multicolumn{2}{|c|}{ CEO Turnover } & \multicolumn{3}{|c|}{ Non-CEO Turnover } \\
\hline Variables $^{\mathrm{a}}$ & Pred. Sign & Coef. & $t$-value ${ }^{\mathrm{b}}$ & & Coef. & $t$-value \\
\hline CONSTANT & & 0.6481 & $1.40^{*}$ & & 1.9853 & $4.93 * * *$ \\
\hline$M I$ & $+1-$ & 0.2906 & $1.70^{*}$ & & -0.4672 & $-1.90 *$ \\
\hline$R O A$ & $+1-$ & -1.3456 & $-3.70^{* * * *}$ & & -1.2280 & $-4.83 * * *$ \\
\hline GROWTH & + & 0.0851 & $1.98^{* *}$ & & 0.0195 & 0.98 \\
\hline SIZE & $+1-$ & -0.0516 & $-1.76^{*}$ & & -0.0363 & $-3.18 * * *$ \\
\hline$L E V$ & + & 0.8469 & $1.68 * *$ & & 0.5081 & $3.47 * * *$ \\
\hline BDSIZE & $+1-$ & 0.0061 & 0.33 & & 0.0143 & $2.17 * *$ \\
\hline$I N D B O D$ & - & -0.7086 & $-2.77 * * *$ & & -0.1575 & $-1.74 * *$ \\
\hline CONTROL & + & 0.1775 & 0.57 & & -0.0132 & -0.19 \\
\hline DEVIATION & + & 0.1633 & 0.43 & & 0.2954 & $1.50^{*}$ \\
\hline DUALITY & + & 0.1446 & $1.41^{*}$ & & -0.0345 & $-1.31 *$ \\
\hline YEAR & & Included & & & Included & \\
\hline$I N D$ & & Included & & & Included & \\
\hline$R^{2}$ & & $9.53 \%$ & & & $5.20 \%$ & \\
\hline $\mathrm{n}$ & & 850 & & & 5,174 & \\
\hline
\end{tabular}

${ }^{a}$ The definitions of the variables reported in this table are: SMOOTH $=$ the standard deviation of net income before extraordinary items from $t-5$ to $t-1$, divided by the standard deviation of cash flow from operations from $t-5$ to $t-1 ; M I=1$ if the company disclosed MI in a given year, otherwise 0;ROA = net income divided by total assets; GROWTH = the percentage increase in sales over one year; SIZE = the natural $\log$ of total assets; $L E V=$ long-term debt divided by total assets; $B D S I Z E=$ number of directors on the board; $I N D B O D=$ number of independent directors on the board divided by the total board size; CONTROL = number of seat-control directors divided by the total board size; DEVIATION = the stock-control right minus the earnings-distribution right; DUALITY $=1$ if the chairman of the board is also the CEO, otherwise $0 ; Y E A R=$ fiscal year dummies; IND = dummy variables controlling for industries.

${ }^{\mathrm{b}}$ Asterisks *, **,*** indicate significance at the $0.10,0.05$, and 0.01 levels, respectively. One-tailed for directional expectations, two-tailed for others. 
Table 10. Restatement and material information disclosure

\begin{tabular}{|c|c|c|c|c|c|c|c|}
\hline \multirow[b]{2}{*}{ Variables $^{\mathrm{a}}$} & \multirow[b]{2}{*}{ Pred. Sign } & \multicolumn{2}{|c|}{ Total sample } & \multicolumn{2}{|c|}{ Big 4} & \multicolumn{2}{|c|}{ Non-Big4 } \\
\hline & & Coef. & $z$-value ${ }^{\mathrm{b}}$ & Coef. & $z$-value & Coef. & $z$-value \\
\hline CONSTANT & & -3.7059 & $-6.04 * * *$ & -4.0993 & $-5.67 * * *$ & -5.1529 & $-3.16 * * *$ \\
\hline$M I$ & $+1-$ & 0.0832 & 1.06 & -0.0217 & -0.24 & 0.4649 & $2.56 * * *$ \\
\hline$R O A$ & $+1-$ & -1.1432 & $-2.79 * * *$ & -0.9104 & $-3.10^{* * * *}$ & -2.9054 & $-3.75 * * *$ \\
\hline GROWTH & + & 0.0351 & 1.01 & 0.0188 & 0.34 & 0.0966 & $2.61 * * *$ \\
\hline SIZE & $+1-$ & 0.0476 & 1.52 & 0.0992 & $2.78 * * *$ & 0.0757 & 0.83 \\
\hline$L E V$ & + & 0.2788 & 0.83 & 0.3208 & 0.74 & 1.2680 & $2.10^{* *}$ \\
\hline BDSIZE & $+1-$ & 0.0041 & 0.21 & -0.0510 & $-1.82^{*}$ & 0.1489 & $4.13^{* * *}$ \\
\hline$I N D B O D$ & - & -0.4293 & $-1.61^{*}$ & -0.4760 & $-1.56^{*}$ & 0.7161 & 1.01 \\
\hline CONTROL & + & -0.1582 & -0.70 & -0.4087 & $-1.52^{*}$ & 0.4546 & 0.91 \\
\hline DEVIATION & + & -0.3583 & -0.95 & -0.2497 & -0.63 & 0.8134 & 0.78 \\
\hline DUALITY & + & 0.1033 & $1.34^{*}$ & 0.1462 & $1.59^{*}$ & -0.2433 & $-1.30^{*}$ \\
\hline YEAR & & Included & & Included & & Included & \\
\hline$I N D$ & & Included & & Included & & Included & \\
\hline Pseudo $\mathrm{R}^{2}$ & & $9.36 \%$ & & $10.29 \%$ & & $31.39 \%$ & \\
\hline $\mathrm{n}$ & & 5,967 & & 4,734 & & 786 & \\
\hline
\end{tabular}

${ }^{a}$ The definitions of the variables reported in this table are: RESTATE $=1$ if the company announces restatements; $M I=1$ if the company disclosed MI in a given year; otherwise $0 ; R O A=$ net income divided by total assets; GROWTH = the percentage increase in sales over one year; $S I Z E=$ the natural $\log$ of total assets; $L E V=$ long-term debt divided by total assets; $B D S I Z E=$ number of directors on the board; $I N D B O D=$ number of independent directors on the board divided by the total board size; $C O N T R O L=$ number of seat-control directors divided by the total board size; DEVIATION = the stock-control right minus the earnings-distribution right; DUALITY= 1 if the chairman of the board is also the $\mathrm{CEO}$, otherwise $0 ; Y E A R=$ fiscal year dummies; IND = dummy variables controlling for industries.

${ }^{\mathrm{b}}$ Asterisks *, **, *** indicate significance at the $0.10,0.05$, and 0.01 levels, respectively. One-tailed for directional expectations, two-tailed for others.

\section{Conclusions}

The purpose of this study was to identify the type of companies that are more likely to disclose MI, and to determine whether the disclosure of MI affects earnings quality and the perceptions of market participants. Our results provide empirical evidence that CSR companies are more likely to disclose MI. We also found that in CSR companies, the disclosure of MI has a favorable effect on firm value as an indicator of quality financial reporting. The reactions to the disclosure of MI vary according to the life cycle stage of the company involved. We also found that the different types of MI differ with regard to their influence on firm value and earnings quality. Further analyses provided evidence that companies experiencing CEO turnover are more likely to engage in earnings management through the disclosure of MI and are therefore associated with poor earnings quality.

In this study, our results show that CSR companies are more willing to fill transparency gaps by disclosing MI than non-CSR companies, and these MI disclosures reflect the perceived of external investors and quality of internal financial reporting. Thus, we suggest that an understanding of these MI disclosures may provide the regulators with insights into the incentives of voluntary disclosures in preventing or detecting irregularities. In this regard, our results should be of interest to regulators, policy-makers, and market participants that desires to better understand the nature of MI disclosures and their economic consequences. Additionally, our study is subject to limitations. First, the sample period was only six years, due to manual collection of data on the nature of MI disclosures via reading news releases of MOPS and GTSM. Second, the skewness of MI disclosures may cause misspecification when this skewness in the dependent variable of Eq. (1).

\section{References}

Abel, A. B., \& Eberly, J. C. (2011). How Q and cash flow affect investment without frictions: An analytic explanation. Review of Economic Studies, 78(4), 1179-1200. http://dx.doi.org/10.1093/restud/rdr006

Al-Akra, M., \& Ali, M. J. (2012). The value relevance of corporate voluntary disclosure in the Middle-East: The case of Jordan. Journal of Accounting and Public Policy, 31(5), 599-549. http://dx.doi.org/10.1016/j.jaccpubpol.2011.10.007

Allayannis, G., \& Weston, J. P. (2001). The use of foreign currency derivatives and firm market value. Review of Financial Studies, 14(1), 243-276. http://dx.doi.org/10.1093/rfs/14.1.243 
Amihud, Y., \& Mendelson, H. (1986). Asset pricing and the bid-ask spread. Journal of Financial Economics, 17(2), 223-249. http://dx.doi.org/10.1016/0304-405X(86)90065-6

Anthony, J., \& Ramesh, K. (1992). Association between accounting performance measures and stock prices: A test of the life cycle hypothesis. Journal of Accounting and Economics, 15(2-3), 203-227. http://dx.doi.org/10.1016/0165-4101(92)90018-W

Bamber, L. S., \& Cheon, Y. S. (1998). Discretionary management earnings forecast disclosures: Antecedents and outcomes associated with forecast venue and forecast specificity choices. Journal of Accounting Research, 36(2), 167-190. http://dx.doi.org/10.2307/2491473

Bamber, L. S., Jiang, J., Petroni, K. R., \& Wang, I. Y. (2010). Comprehensive income: Who's afraid of performance reporting? The Accounting Review, 85(1), 97-126. http://dx.doi.org/10.2308/accr.2010.85.1.97

Barry, C. B., \& Brown, S. J. (1986). Limited information as a source of risk. The Journal of Portfolio Management, 12(2), 66-72. http://dx.doi.org/10.3905/jpm.1986.409052

Bartholdson, D. S., \& Goethe, D. J. (2011). A study of the relationship between voluntary disclosure quality, earnings quality and cost of equity capital. Journal of International Financial Management and Accounting, 11, 1-52. http://dx.doi.org/10.1109/ICMSE.2006.31425

Beasley, M. S. (1996). An empirical analysis of the relation between the board of director composition and financial statement fraud. The Accounting Review, 71(4), 443-465. http://dx.doi.org/10.1016/j.adiac.2010.10.004

Bens, D. A., Heltzer, W., \& Segal, B. (2011). The information content of goodwill impairments and SFAS 142, Journal of Accounting, Auditing \& Finance, 26(3), 527-555. http://dx.doi.org/10.1177/0148558X11401551

Bhattacharya, C. B., \& Sen, S. (2004). Doing better at doing good: When, why and how consumers respond to

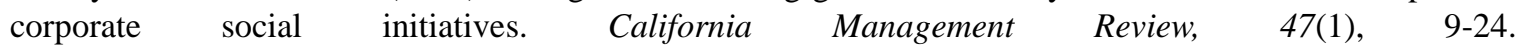
http://dx.doi.org/10.2307/41166284

Black, B., Jang, H., \& Kim, W. (2006). Does corporate governance predict firms' market values? Evidence from Korea. Journal of Law, Economics, and Organization, 22(2), 366-413. http://dx.doi.org/10.1093/jleo/ewj018

Black, E. (1998). Life-cycle impacts on the incremental value-relevance of earnings and cash flow measures. Journal of Financial Statement Analysis, 4(1), 40-56. http://dx.doi.org/10.230/2491387

Bloomfield, R. (2008). Discussion of: Annual report readability, current earnings, and earnings persistence. Journal of Accounting and Economics, 45(2-3), 248-252. http://dx.doi.org/10.1016/j.jacceco.2008.04.002

Bosworth, D. (2002). The returns to R\&D in Tobin q models and the option value of future R\&D. Economics Letters, 77(3), 439-444. http://dx.doi.org/10.1016/S0165-1765(02)00168-4

Botosan, C. A. (1997). Disclosure level and the cost of equity capital. The Accounting Review, 72(3), 323-350. http://dx.doi.org/10.2139/ssrn.224385

Brav, A., \& Gompers, P. A. (2003). The role of lock-ups in initial public offerings. Review of Financial Studies, 16(1), 1-29. http://dx.doi.org/10.1093/rfs/16.1.1

Brickley, J. A., Linck, J. S., \& Coles, J. L. (1999). What happens to CEOs after they retire? New evidence on career concerns, horizon problems, and CEO incentives. Journal of Financial Economics, 52(3), 341-377. http://dx.doi.org/10.1016/S0304-405X(99)00012-4

Brown, L. D., \& Caylor, M. L. (2006). Corporate governance and firm valuation. Journal of Accounting and Public Policy, 25(4), 409-434. http://dx.doi.org/10.1016/j.jaccpubpol.2006.05.005

Brown, S., Hillegeist, S. A., \& Lo, K. (2009). The effect of earnings surprises on information asymmetry. Journal of Accounting and Economics, 47(3), 208-225. http://dx.doi.org/10.1016/j.jacceco.2008.12.002

Burgstahler, D. C., Hail, L., \& Leuz, C. (2006). The Importance of reporting incentives: Earnings management in European private and public firms. The Accounting Review, 81(5), 983-1016. http://dx.doi.org/10.2308/accr.2006.81.5.983

Chung, K., \& Pruitt, S. (1994). A simple approximation of Tobin's Q. Financial Management, 23(3), 70-74. http://dx.doi.org/0.2307/3665623

Chung, K. H., Wright, P., \& Kedia, B. (2003). Corporate governance and market valuation of capital and R\&D $\begin{array}{lllll}\text { investments. Review } & \text { 161-172. }\end{array}$ 
http://dx.doi.org/10.1016/S1058-3300(02)00063-0

Coles, J. L., Daniel, N. D., \& Naveen, L. (2008). Boards: Does one size fit all? Journal of Financial Economics, 87(2), 329-356. http://dx.doi.org/10.1016/j.jfineco.2006.08.008

Connolly, R. A., \& Hirschey, M. (2005). Firm size and the effect of R\&D on Tobin's Q. R\&D Management, 35(2), 217-223. http://dx.doi.org/10.1111/j.1467-9310.2005.00384.x

Conyon, M. J., \& Florou, A. (2004). Does governance quality mitigate horizon effects? Investment patterns surrounding CEO departures. Working papers. Retrieved from http://ssrn.com/abstract=545982

Core, J. E. (2001). A review of the empirical disclosure literature: Discussion. Journal of Accounting and Economics, 31(1-3), 441-456. http://dx.doi.org/10.1016/S0165-4101(01)00036-2

Daske, H., Hail, L., Leuz, C., \& Verdi, R. (2008). Mandatory IFRS Reporting around the world: Early evidence on the economic consequences. Journal of Accounting Research, 46(5), 1085-1142. http://dx.doi.org/10.1111/j.1475-679X.2008.00306.x

Davis, A. K., Piger, J. M., \& Sedor, L. M. (2012). Beyond the numbers: Measuring the information content of earnings press release language. Contemporary Accounting Research, 29(3), 845-868. http://dx.doi.org/10.1111/j.1911-3846.2011.01130.x

Dechow, P. M., \& Sloan, R. G. (1991). Executive incentives and the horizon problem: An empirical investigation. Journal of Accounting and Economics, 14(1), 51-89. http://dx.doi.org/10.1016/0167-7187(91)90058-S

Dechow, P. M., Sloan, R. G., \& Sweeney, A. P. (1996). Causes and consequences of e earnings manipulation: An analysis of firms subject to enforcement actions by the SEC. Contemporary Accounting Research, 13(1), 1-36. http://dx.doi.org/10.1111/j.1911-3846.1996.tb00489.x

DeFond, M. L., \& Subramanyam, K. R. (1998). Auditor changes and discretionary accruals. Journal of Accounting and Economics, 25(1), 35-67. http://dx.doi.org/10.1016/S0165-4101(98)00018-4

DeJong, A., DeJong, D. V., Mertens, G. M. H., \& Wasley, C. E. (2005). The role of self-regulation in corporate governance: Evidence and implications from the Netherlands. Journal of Corporate Finance, 11(3), 473-503. http://dx.doi.org/10.1016/j.jcorpfin.2004.01.002

Dhaliwal, D. S., Li, O. Z., Tsang, A., \& Yang, Y. G. (2011). Voluntary nonfinancial disclosure and the cost of equity capital: The initiation of corporate social responsibility reporting. The Accounting Review, 86(1), 59-100. http://dx.doi.org/10.2308/accr.00000005

Diamond, D., \& Verrecchia, R. (1991). Disclosure, liquidity, and the cost of capital. The Journal of Finance, 46(4), 1325-1359. http://dx.doi.org/10.2307/2328861

Diamond, D. W. (1985). Optimal release of information by firms. The Journal of Finance, 40(4), 1071-1094. http://dx.doi.org/10.2307/2328395

Ecker, F., Francis, J., Olsson, P., \& Schipper, K. (2011). Peer firm selection for discretionary accruals models. Working paper, Duke University.

Eltayeb, A. M. (2011). Do market valuation effects of market-to-book ratio and Q estimators systematically affect the financial leverage of Japanese Firms? International Research Journal of Finance and Economics, 78, 193-209. http://dx.doi.org/10.1111/j.1540-6288.1983.tb01883.x

Ertimur, Y., Sletten, E., \& Sunder, J. (2011). Large Shareholders and Disclosure Strategies: Evidence from IPO Lockup Expirations. Working paper, Duke University, Boston College, and The University of Arizona. http://dx.doi.org/10.2139/ssrn.817184

Ettredge, M., Heintz, J., Li, C., \& Scholz, S. W. (2011). Auditor realignments accompanying implementation of SOX 404 ICFR reporting requirements. Accounting Horizons, 25(1), 17-39. http://dx.doi.org/10.2308/acch.2011.25.1.17

Fisher, F. M., \& McGowan, J. J. (1983). On the misuse of accounting rates of return to infer monopoly profits. American Economic Review, 73(1), 82-97. http://dx.doi.org/10.2307/2555603

Francis, J., LaFond, R. P., Olsson, M., \& Schipper, K. (2004). Costs of equity and earnings attributes. The Accounting Review, 79(4), 967-1010. http://dx.doi.org/10.2308/accr.2004.79.4.967

Francis, J., Nanda, D., \& Olsson, P. (2008). Voluntary disclosure, earnings quality, and cost of capital. Journal of Accounting Research, 46(1), 53-99. http://dx.doi.org/10.1111/j.1475-679X.2008.00267.x 
Frankel, R. M., Johnson, M. F., \& Nelson, K. K. (2002). The relation between auditors' fees for non-audit services and earnings management. The Accounting Review, 77(Supplement), 71-105. http://dx.doi.org/10.2308/accr.2002.77.s-1.71

Gassen, J., Flbier, R. U., \& Sellhorn, T. (2006). International differences in conditional conservatism-The role of unconditional conservatism and income smoothing. European Accounting Review, 15(4), 527-564. http://dx.doi.org/10.1080/09638180601102107

Glosten, L. R., \& Milgrom, P. R. (1985). Bid, ask, and transaction prices in a specialist market with heterogeneously informed traders. Journal of Financial Economics, 14(1), 71-100. http://dx.doi.org/10.1016/0304-405X(85)90044-3

Godfrey, J., Mather, P., \& Ramsay, A. (2003). Earnings and impression management in financial reports: The case of CEO changes. Abacus, 39(1), 95-123. http://dx.doi.org/10.1111/1467-6281.00122

Greenstein, M. M., \& Sami, H. (1994). The impact of the SEC's segment disclosure requirement on bid-ask spreads. The Accounting Review, 69(1), 179-199. http://dx.doi.org/10.1111/j.0306-686X.2005.00632.x

Grossman, S. (1981). The informational role of warranties and private disclosure about product quality. Journal of Law and Economics, 24(3), 461-483. http://dx.doi.org/10.1086/466995

Hamada, R. S. (1972). The effect of the firm's capital structure on the systematic risk of common stocks. Journal of Finance, 27(2), 435-452. http://dx.doi.org/10.2307/2978486

Healy, P., \& Palepu, K. (2001). Information asymmetry, corporate disclosure, and the capital markets: A review of the empirical disclosure literature. Journal of Accounting and Economics, 31(1-3), 405-440. http://dx.doi.org/10.1016/S0165-4101(01)00018-0

Healy, P. M., \& Palepu, K. G. (1993). The effect of firms' financial disclosure strategies on stock prices. Accounting Horizons, 7(1), 1-11. http://dx.doi.org/10.2139/ssrn.2020840

Henry, E. (2008). Are investors influenced by how earnings press releases are written? Journal of Business Communication, 45(4), 363-407. http://dx.doi.org/10.1177/0021943608319388

Iatridis, G., \& Alexakis, P. (2012). Evidence of voluntary accounting disclosures in the Athens Stock Market. Review of Accounting and Finance, 11(1), 73-92. http://dx.doi.org/10.1108/14757701211201830

Jelic, R., Saadouni, B., \& Briston, R. (1998). The accuracy of earnings forecast in IPO prospectuses on the Kuala Lumpur Stock Exchange 1984-1995. Accounting and Business Research, 29(1), 57-72. http://dx.doi.org/10.1080/00014788.1998.9729566

Joseph, F. (2012). Comparing the informativeness of two income smoothing measures. Journal of Interdisciplinary Business Studies, 1, 1-45. http://dx.doi.org/10.1016/j.intacc.2011.07.005

Kennedy, P. (1998). A Guide to Econometrics (4th ed.). Cambridge, MA: The MIT Press.

Kim, O., \& Verrecchia, R. E. (1994). Market liquidity and volume around earnings announcements. Journal of Accounting \& Economics, 17(1-2), 41-67. http://dx.doi.org/10.1016/0165-4101(94)90004-3

Klein, A. (2002a). Audit committee, board of director characteristics, and earnings management. Journal of Accounting \& Economics, 33(3), 375-400. http://dx.doi.org/10.1016/S0165-4101(02)00059-9

Klein, A. (2002b). The economic determinants of audit committee independence. The Accounting Review, 77(2), 435-452. http://dx.doi.org/10.2308/accr.2002.77.2.435

Kohlbeck, M., \& Mayhew, B. W. (2010). Valuation of firms that disclose related party transactions. Journal of Accounting and Public Policy, 29(2), 115-137. http://dx.doi.org/10.1016/j.jaccpubpol.2009.10.006

Kravet, T., \& Muslu, V. (2013). Textual risk disclosures and investors' risk perceptions. Review of Accounting Studies, 18(4), 1088-1122. http://dx.doi.org 10.1007/s11142-013-9228-9

Kristandl, G., \& Bontis, N. (2007). The impact of voluntary disclosure on cost of equity capital estimates in a $\begin{array}{lllll}\text { temporal setting. Journal of Intellectual Capital, } & \text { 8(4), }\end{array}$ http://dx.doi.org/10.1108/14691930710830765

Lang, L. H. P., \& Stulz, R. M. (1994). Tobin's Q, corporate diversification, and firm performance. Journal of Political Economy, 102(6), 1248-1280. http://dx.doi.org/10.1086/261970

Lang, M. H., \& Lundholm, R. J. (2000). Voluntary disclosure and equity offerings: Reducing information asymmetry or hyping the stock? Contemporary Accounting Research, 17(4), 623-662. 
http://dx.doi.org/10.1506/9N45-F0JX-AXVW-LBWJ

Lang, M., Lins, K., \& Maffett, M. (2012). Transparency, liquidity, and valuation: International evidence on when transparency matters most. Journal of Accounting Research, 50(3), 729-774. http://dx.doi.org/10.1111/j.1475-679X.2012.00442.x

Lang, M., Raedy, J., \& Yetman, M. (2003). How representative are firms that are cross-listed in the United States? An analysis of accounting quality. Journal of Accounting Research, 41(2), 363-386. http://dx.doi.org/10.1111/1475-679X.00108

Leuz, C., \& Verrecchia, R. (2000). The economic consequences of increased disclosure. Journal of Accounting Research, 38(3), 91-124. http://dx.doi.org/10.2307/2672911

Leuz, C., Nanda, D., \& Wysocki, P. D. (2003). Earnings management and investor protection: An international $\begin{array}{lllll}\text { comparison. Journal of Financial } & \text { Economics, }\end{array}$ http://dx.doi.org/10.1016/S0304-405X(03)00121-1

Li, F. (2006). Do stock market investors understand the risk sentiment of corporate annual reports? Working Paper, University of Michigan. http://dx.doi.org/10.2139/ssrn.898181

Li, F. (2008). Annual report readability, current earnings, and earnings persistence. Journal of Accounting and Economics, 45(2-3), 221-247. http://dx.doi.org/10.1016/j.jacceco.2008.02.003

$\mathrm{Li}$, S. (2010). Does mandatory adoption of international financial reporting standards in the European Union reduce the cost of equity capital? The Accounting Review, 85(2), 607-636. http://dx.doi.org/10.2308/accr.2010.85.2.607

Lobo, G. J., \& Zhou, J. (2001). Disclosure quality and earnings management. Asia-Pacific Journal of Accounting \& Economics, 8(1), 1-20. http://dx.doi.org/10.1080/16081625.2001.10510584

Logue, D. E. (1973). On the pricing of unseasoned equity issues: 1965-1969. Journal of Financial and Quantitative Analysis, 8(1), 91-103. http://dx.doi.org/10.2307/2329751

Loughran, T., \& Mcdonald, B. (2011). When is a liability not a liability? Textual analysis, dictionaries, and 10-Ks. The Journal of Finance, 66(1), 35-65. http://dx.doi.org/10.2469/dig.v41.n2.20

Lundholm, R. J. (1991). Public signals and the equilibrium allocation of private information. Journal of Accounting Research, 29(2), 322-350. http://dx.doi.org/10.2307/2491052

Mandelker, G. N., \& Rhee, S. G. (1984). The impact of the degrees of operating and financial leverage on systematic risk of common stock. Journal of Financial and Quantitative Analysis, 19(1), 45-57. http://dx.doi.org/10.2307/2331000

Martinez, A. L., \& Castro, M. A. R. (2010). The smoothing hypothesis, stock returns and risk in Brazil. Brazilian Administration Review, 8(1), 1-20. http://dx.doi.org/10.5817/FAI2013-2-3

Merkley, K. J. (2014). Narrative disclosure and earnings performance: Evidence from R\&D disclosures. Accounting Review, 89(2), 725-57. http://dx.doi.org/10.2308/accr-50649

Michelson, S. E., Jordan-Wagner, J., \& Wootton, C. W. (1995). A market based analysis of income smoothing. Journal of Business Finance and Accounting, 22(8), 1179-1193. http://dx.doi.org/10.1111/j.1468-5957.1995.tb00900.x

Milgrom, P. (1981). Good news and bad news: Representation theorems and applications. The Bell Journal of Economics, 12(2), 380-391. http://dx.doi.org/10.2307/3003562

Mohammadi, S., Maharlouie, M. M., \& Mansouri, O. (2012). The effect of cash holdings on income smoothing, Interdisciplinary. Journal of Contemporary Research in Business, 4(2), 523-533. http://dx.doi.org/10.1016/j.jcorpfin.2010.01.003

Morck, R., Shleifer, A., \& Vishny, R. W. (1988). Management ownership and market valuation: An empirical $\begin{array}{lllll}\text { analysis. Journal of } & \text { Financial 293-315. }\end{array}$ http://dx.doi.org/10.1016/0304-405X(88)90048-7

Myers, J. N., Myers, L. A., \& Skinner, D. J. (2007). Earnings momentum and earnings management. Journal of Accounting, Auditing and Finance, 22(2), 249-284. http://dx.doi.org/10.2139/ssrn.741244

Nagar, V., Nanda, D., \& Wysocki, P. (2003). Discretionary disclosure and stock-based incentives. Journal of Accounting and Economics, 34(1-3), 283-309. http://dx.doi.org/10.1016/S0165-4101(02)00075-7 
Nissim, D. (2002). Discussion of the role of volatility in forecasting. Review of Accounting Studies, 7(2-3), 217-227. http://dx.doi.org/10.1023/A:1020278103044

Noravesh, I., \& Hosseini, S. A. (2009). The relationship between disclosure quality (reliability and timeliness) and earnings management. Accounting and Auditing Studies, 16(55), 117-134. http://dx.doi.org/10.1001/jama.288.12.1484

Piotroski, J. (1999). The impact of newly reported segment information on market expectations and stock prices. Working paper, University of Chicago.

Plumlee, M., \& Yohn, T. L. (2010). An analysis of the underlying causes attributed to restatements. Accounting Horizons, 24(1), 41-64. http://dx.doi.org/10.2308/acch.2010.24.1.41

Pourciau, S. (1993). Earnings management and nonroutine executive changes. Journal of Accounting and Economics, 16(1-3), 317-336. http://dx.doi.org/10.1016/0165-4101(93)90015-8

Price, S. M., Doran, J. S., Peterson, D. R., \& Bliss, B. A. (2012). Earnings conference calls and stock returns: The incremental informativeness of textual tone. Journal of Banking \& Finance, 36(4), 992-1011. http://dx.doi.org/10.1016/j.jbankfin.2011.10.013

Reitenga, A., \& Tearney, M. (2003). Mandatory CEO retirements, discretionary accruals, and corporate governance changes. Journal of Accounting Auditing and Finance, 18(3), 255-280. http://dx.doi.org/10.1111/j.1467-629X.2009.00321.x

Reynolds, J. K., \& Francis, J. R. (2000). Does size matter? The influence of large clients on office-level auditor reporting decisions. Journal of Accounting and Economics, 30(3), 375-400. http://dx.doi.org/10.1016/S0165-4101(01)00010-6

Sengupta, P. (1998). Corporate disclosure quality and the cost of debt. The Accounting Review, 73(4), 459-474. http://dx.doi.org/10.2139/ssrn.933615

Tucker, J. W., \& Zarowin, P. A. (2006). Does income smoothing improve earnings informativeness? The Accounting Review, 81(1), 251-270. http://dx.doi.org/10.2308/accr.2006.81.1.251

Verrecchia, R. E. (2001). Essays on disclosure. Journal of Accounting \& Economics, 32(1-3), 97-180. http://dx.doi.org/10.1016/S0165-4101(01)00025-8

Welker, M. (1995). Disclosure policy, information asymmetry, and liquidity in equity markets. Contemporary Accounting Research, 11(2), 801-827. http://dx.doi.org/10.1111/j.1911-3846.1995.tb00467.x

Wells, P. (2002). Earnings management surrounding CEO changes. Accounting \& Finance, 42(2), 169-193. http://dx.doi.org/10.1111/1467-629X.0007350(2),

Wilson, M., \& Wang, L. W. (2010). Earnings management following chief executive officer changes: The effect of contemporaneous chairperson and chief financial officer appointments. Accounting \& Finance, 50(2), 447-480. http://dx.doi.org/10.1111/j.1467-629X.2009.00324.x

\section{Copyrights}

Copyright for this article is retained by the author(s), with first publication rights granted to the journal.

This is an open-access article distributed under the terms and conditions of the Creative Commons Attribution license (http://creativecommons.org/licenses/by/3.0/). 